\title{
Synthesis of naphthoquinone derivatives with potential pharmacological activity
}

\author{
Alex Antonio de Oliveira, Carlos Kleber Z. Andrade* \\ Laboratório de Química Metodológica e Orgânica Sintética (LaQMOS), Instituto de Química, Universidade \\ de Brasília, CP-4478, 70910-970 Brasília-DF, Brasil \\ *ckleber@unb.br
}

Keywords: naphthoquinone, triazole and chalcone.

\section{INTRODUCTION}

Compounds that have triazoles, chalcone and quinone nuclei, separately or together with other nuclei, have important pharmacological properties such as antibacterial, antifungal, antiprotozoal, antiviral, antiallergic, anticancer, antiinflammatory, among others ${ }^{1-6}$.

In this work, we propose the synthesis of molecules bearing in their structures these 3 important nuclei (Figure 1).<smiles>[3H]/C=C/C(=O)c1cn(C2=CC(=O)c3ccccc3C2=O)nn1</smiles>

Figure 1. Naphthoquinone derivatives with triazole and chalcone nuclei.

\section{RESULTS AND DISCUSSION}

The synthesis begins by generating the naphthoquinone nucleus by the reaction of naphthol reacted with NBS ( $N$-Bromosuccinimide) leading to 2-bromo-1,4-naphthoquinone 2 in $80 \%$ yield, following the methodology of Heinzman and Grunwell $^{6}$ (Scheme 1). The 2-azido-1,4naphthoquinone 3 was obtained in $85 \%$ from 2 by reaction with $\mathrm{NaN}_{3}$. The second nucleus is generated by a click reaction between 2-azido-1,4naphthoquinone $\mathbf{3}$ and 3-butyn-2-ol in the presence of copper I, generated by mixing sodium ascorbate and copper sulfate II. The alcohol group in $\mathbf{4}$ was oxidized using $\mathrm{MnO}_{2}$. The last step of the synthesis involves the formation of the chalcone nucleus and this stage is currently under investigation. Initial results pointed to the instability of the product under basic conditions and we are now trying to solve this problem.
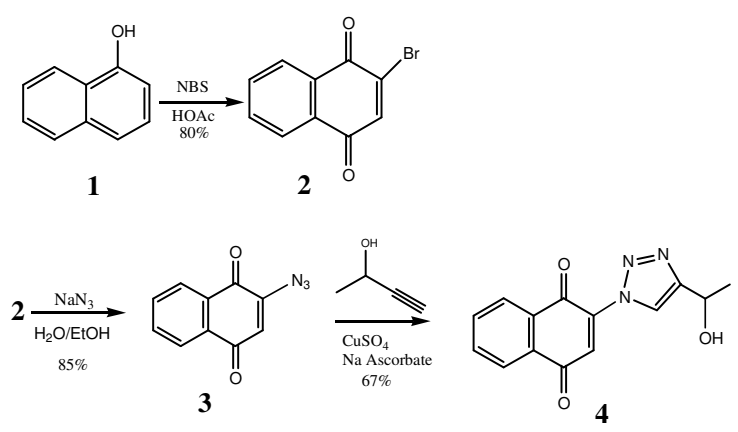<smiles>CC(=O)c1cn(C2=CC(=O)c3cc(C=[V])ccc3C2=O)nn1</smiles><smiles>C#CI</smiles><smiles>[13CH3]/C=C/C(=O)c1cn(C2=CC(=O)c3ccccc3C2=O)nn1</smiles>

Scheme 1. Synthetic sequence for the synthesis of naphthoquinone derivatives with triazole and chalcone nuclei.

\section{CONCLUSION}

Compound $\mathbf{5}$ was efficiently obtained in a 4 -step sequence with $27 \%$ overall yield and the formation of the chalcone nucleus is in progress in our laboratory.

\section{ACKNOWLEDGEMENTS}

IQ-UnB,CNPq and FINEP-CTINFRA n 0970/01.

\section{REFERENCES}

${ }^{1}$ Appukkuttan, P.; Dehaen, W.; Fokin, V. V.; der Eycken, E. V.; Org. Lett. 2004, 6, 4223.

2 Cronin, S. S.; Chandrasekar, P. H.; J. Antimicrob. Chemother. 2010, 65, 410.

${ }^{3}$ Melo, J. O. F.; Donnici, C. L.; Augusti, R.; Ferreira, V. F.; Souza, M. C. B. V.; Ferreira, M. L. G.; Cunha, A. C.; Quim. Nova 2006, 29, 569.

${ }^{4}$ Buckle, D. R.; Smith, H.; Spicer, B. A.; Tedder, J. M.; J. Med. Chem. 1983, 26, 714.

${ }^{5}$ Cronin, S., Chandrasekar, P. H.; J. Antimicrob. Chemother. 2010, 65, 410.

${ }^{6}$ Heinzman, S. W.; Grunwell, J. R.; Tetrahedron Lett. 1980, 21, 4305. 